\title{
Fruit flies in a guava orchard in Indiana county, São Paulo, southeastern Brazil
}

\author{
Moscas de las frutas en el cultivo de guayaba en Indiana, São Paulo, Brasil \\ Renata Espolador São João ${ }^{1}$, Sônia Maria N. M. Montes ${ }^{2 *}$, Adalton Raga ${ }^{2}$
}

\begin{abstract}
The experiment was performed from September, 2011 until April, 2012 in order to determine the infestation stage of fruits, the population dynamics and the diversity of fruit files (Diptera: Tephritidae) in a guava orchard in the western region of São Paulo State, Brazil. The population dynamics of fruit flies were obtained from three McPhail plastic traps baited with hydrolyzed protein. To evaluate the infestation of fruit flies, 180 fruits were chosen in which fifteen of them were fortnightly bagged or unbagged. Fruit length and diameter were measured to define the fruit development stage most susceptible to natural fruit fly infestation. We captured a total of 300 Tephritidae specimens: 102 specimens of Anastrepha spp. (34.1\%) and 198 of Ceratitis capitata (Wied.) (65.9\%). Four species of Anastrepha fraterculus (Wied.), were recovered from McPhail traps: A. obliqua (Macquart), A. striata Schiner and A. sororcula Zucchi. A total of 31 adults were found in the fruits: 2 C. capitata (6.5\%) and 29 Anastrepha (93.5\%); A. obliqua and A. sororcula. Fruits with $2.6-\mathrm{cm}$ of mean diameter were infested by fruit flies.
\end{abstract}

Key words: Anastrepha spp., Ceratitis capitata, Psidium guajava, population dynamics.

\section{RESUMEN}

El experimento fue realizado entre septiembre de 2011 hasta abril de 2012 con el objetivo de evaluar la fase de infestación de frutos, la dinámica poblacional y la diversidad de moscas de la fruta (Diptera: Tephritidae) en guayabales en la región oeste del estado de São Paulo, Brasil. La dinámica poblacional fue cuantificada por medio de tres trampas amarillas modelo McPhail con sustancia a base de proteína hidrolisada. Para evaluar la infestación por moscas de la fruta se escogieron 180 frutos que fueron colocados y sacados de los sacos cada quince días. Se midió longitud y diámetro de los frutos para determinar la fase de desarrollo susceptible al ataque de las moscas de la fruta. Se recogieron 300 individuos de Tephritidae en las trampas, de las cuales 102 (34,1\%) fueron especies de Anastrepha spp. y 198 (65,9\%) de Ceratitis capitata (Wied.). Se identificaron cuatro especies de Anastrepha spp.: A. fraterculus (Wied.), A. obliqua (Macquart), A. striata Schinery A. sororcula Zucchi. Se identificaron 31 adultos en los frutos, siendo dos (6,5\%) de C. capitata y 29 (93,5\%) del Anastrepha spp. (A. obliqua y A. sororcula). Se observó que los frutos con diámetro superior a 2,6 cm fueron sensibles al ataque de moscas de la fruta.

Palabras clave: Anastrepha spp., Ceratitis capitata, Psidium guajava, dinámica poblacional.

\section{Introduction}

Guava (Psidium guajava L.) is currently grown as a crop in most of the tropical and subtropical regions in the world. With its origin in tropical America, guava plants are naturally distributed from Mexico to southern Brazil. Essentially based on family labor, guava cropping has great economic and social importance (Pereira, 1995).

In Brazil, São Paulo State is by far the largest national producer of guava, with around 1.8 million producing trees. Guava yield data from 2001 indicated an estimated production of 172,300 ton. This high volume of guava production was intended for both table consumption and industry (IEA, 2011).

Despite the high importance of guava as a commodity in Brazil, the amount of guava exports is very low (Costa et al., 2007). The commercialization restricted to the within-country market is basically due to strict quarantine regulations abroad. The prevalence of an exotic pest such as fruit flies (Diptera: Tephritidae) associated with guava fruits

1 Apta Regional Alta Sorocabana/APTA . Rodovia Raposo Tavares km 561 Caixa postal 298 CEP 19015-970 Presidente Prudente, SP. Brasil

2 Instituto Biológico, Centro Experimental, Rodovia Heitor Penteado km 3, Caixa postal 70, CEP 13001-970, Campinas, SP, Brasil.

* Autor para correspondência: soniamontes@apta.sp.gov.br

Fecha de Recepción: 24 Junio, 2014.

Fecha de Aceptación: 9 Junio, 2014. 
is possibly the most important factor limiting guava exports (Gould and Raga, 2002).

In fact, fruit flies are considered major pests for several fruit trees worldwide because of their constancy and polyphagous habits. Particularly in Brazil, guava crops are extremely susceptible to fruit fly infestation. The fruit fly species Anastrepha and Ceratitis capitata (Wied) are probably the most prevalent guava pests in Brazil (Pereira and Martinez Junior, 1986; Raga et al., 2005).

Fruit fly infestation is influenced by the degree of fruit development and ripening. Fruit flies cannot easily penetrate the resistant epidermis of young guava fruits. Fruit flies are not attracted by fully ripe fruits, which would represent a short period for insect development. (Salles, 1994). The optimum guava fruit size for fruit fly infestation is the two cm-diameter growth stage (Souza-Filho et al., 2009).

One aspect of fundamental importance in the management of fruit flies is the monitoring of the existing population in orchards, which should provide information that adequately represents the behavior of the populations (Scoz et al., 2006). Trap evaluation and food baits were performed by $\mathrm{Scoz}$ et al. (2006). They showed that alternative traps different from the McPhail design, built from 2 liter transparent and green PET bottles, are efficient in capturing A. fraterculus.

This study aimed to determine the population dynamics, the infestation stage of the fruit and the diversity of fruit flies from guava orchards in the western region of São Paulo State, Brazil, to subsidize an integrated pest management program and to help make family fruit farming viable.

\section{Material and Methods}

This study was conducted in a commercial guava orchard located in Indiana county, SP, Brazil (22 $2^{\circ} 10^{\prime} 05.6^{\prime \prime} \mathrm{S}, 51^{\circ} 15^{\prime} 24.8^{\prime \prime} \mathrm{W}$ and $446 \mathrm{~m}$ altitude) from September 2011 to April 2012. The orchard was planted with four-year old guava cv. Paluma with trees distributed in a $6 \times 7 \mathrm{~m}$ spacing and conducted under conventional system during the experiment.

To determine the population dynamics of the adult fruit flies, three McPhail-type traps containing $400 \mathrm{~mL}$ of attractive solution composed of $5 \%$ $\mathrm{v} / \mathrm{v}$ of hydrolyzed protein (BioAnastrepha ${ }^{\circledR}$ ) were used. One of the traps was installed in the center of the orchard, while the other two were set near the outskirts, in opposite positions. The attractive solution was renewed weekly and insects from the previous week were collected and taken to the laboratory to proceed with the tephritid classification.

Fifteen days after flowering (October $5^{\text {th }}, 2011$ ), when the fruits presented an average diameter of $1.30 \mathrm{~cm}, 180$ guava fruits were randomly chosen and bagged to determine the fruit growth stage most susceptible to Tephritidae infestation. Every two weeks fifteen fruits were bagged or unbagged, making a total of 30 fruits per evaluation (Table 2). A colored band was tied to the fruit to indicate the exposure date and the corresponding fruit growth stage exposed to fruit fly infestation.

When ripe, the fruit were collected and transported to the laboratory, where they were placed in $500 \mathrm{~mL}$ cups containing a mixture of vermiculite and sand, covered with aluminum foil and strapped with an elastic band. After approximately 25 days, the fruits were removed and the substrates containing pupae were maintained until the emergence of the flies.

The Anastrepha spp. fruit flies were separated and preserved in glass bottles filled with $70 \%$ alcohol for posterior identification. Because $C$. capitata is the only species of the genus Ceratitis in Brazil, the number of specimens were recorded and then discarded once no further identification would be necessary (Zucchi, 2000a). The female Anastrepha were identified based on the terminalia, observing the specific aculeus characteristics according to the keys of Steyskal (1977) and Zucchi (2000b). To measure the population level of the Anastrepha spp. and $C$. capitata in the orchard, the numbers of individuals collected weekly were transformed into flies.trap ${ }^{-1}$.day ${ }^{-1}$ (FTD).

\section{Results and Discussion}

\section{Population dynamics of fruit flies}

From October 2011 to February 2012 a total of 300 Tephritidae specimens were collected from the traps installed in the guava orchard. There were a total of $34.3 \%$ Anastrepha spp. specimens (24.3\% males and $75.7 \%$ females) and $65.7 \%$ C. capitata specimens (31.5\% males and $68.5 \%$ females). $A$. obliqua Macquart, A. fraterculus (Wied.), A. sororcula Zucchi and A. striata Schinner were captured in the traps, with predominance of A. obliqua (Table 1).

Surveys carried out by Montes et al. (2012) in the same area of this study in western São Paulo 
Table 1. Fruit flies collected in McPhail traps in a guava orchard in the county of Indiana, SP, Brazil. From Sept/2011 to Apr/2012.

\begin{tabular}{lcccr}
\hline \multirow{2}{*}{\multicolumn{1}{c}{ Species of fruit flies }} & \multicolumn{2}{c}{ Specimens collected in the traps $\left(\mathrm{n}^{\circ}\right)$} & Relative frequency $(\%)$ \\
\cline { 2 - 4 } & Male & Female & Total & 65.67 \\
\hline Ceratitis capitata Wied. & 62 & 135 & 197 & 34.33 \\
Anastrepha spp. & 25 & 78 & 103 & 100.00 \\
Total & 87 & 213 & 300 & 12.82 \\
Species of Anastrepha & & & 10 & 32.05 \\
Anastrepha fraterculus (Wied.) &. &. & 25 & 50.00 \\
Anastrepha sororcula Zucchi &. &. & 39 & 5.13 \\
Anastrepha obliqua Macquart &. &. & 7 & 100.00 \\
Anastrepha striata Schinner &. &. & 78 & \\
Total & & & \\
\hline
\end{tabular}

State recorded the occurrence of the same Anastrepha species, C. capitata, and five other species of Lonchaeidae: Neosilba certa (Walker), N. inesperata Strikis \& Prado, N. pendula (Bezzi), N. pradoi Strikis $\&$ Perena and N. zadolicha McAlphine \& Steyskal on peaches, coffee, mangoes, siriguela (Spondias purpurea), cassava, pumpkin and citrus crops. The authors also recorded the occurrence of $A$. barbiellinii Lima, A. montei Lima, A. pseudoparalella (Loew), A. daciformis Bezzi, A. haywardi Blanchard, A. zenildae Zucchi, A. leptozona Hendel, A. bistrigata Bezzi, A. amita Zucchi, A. dissimilis Stone, A. distincta Greene, A. elegans Blanchard and an unidentified species of Anastrepha.

Raga et al. (2005) reported an infestation by $C$. capitata, A. fraterculus, A. bistrigata, A. sororcula, A. obliqua, A. montei and A. dissimilis in guavas from São Paulo State. Araújo and Zucchi (2003) recorded a similar result in guava orchards from Mossoró, Rio Grande do Norte State (Northeastern Brazil), reporting the occurrence of $C$. capitata and six Anastrepha species on traps: A. zenildae, A. sororcula, A. obliqua, A. montei, A. dissimilis and Anastrepha sp.

From October $26^{\text {th }}$ to December $7^{\text {th }} 2011$ no Anastrepha were captured. A population peak of Anastrepha spp. was observed on February $1^{\text {st }} 2012$, reaching a FTD value of 5.6 (Figure 1), when the orchard already had developing fruits. In Mossoro, Araújo and Zucchi (2003) also noted that between November and December guavas were free from fruit fly infestation

Adults of C. Capitata represented the most abundant trap-captured species in the guava orchard (Figure 2), differing from other studies on fruit fly diversity from the same location. The high abundance of $C$. capitata is due probably to the proximity of the guava orchard to a coffee plantation, which is the preferential host of this fly species. The coffee trees in the adjacent area were not fruiting, and so would not attract the flies. In Presidente Prudente, SP, the predominance of $C$. capitata was also noticed in trap surveys conducted on peaches, coffee and mango trees (Montes et al. 2010; 2011 b; 2012). A distinct result was documented by Azevedo et al. (2010) in Crato, Ceara (Northeastern Brazil), in which a low constancy index of $C$. capitata individuals was observed. However, the mostly-dry semi-arid weather conditions of Northeastern Brazil, which are completely distinct from the humid summer of Southeastern Brazil, might have interfered with the occurrence of $C$. capitata.

The population peaks of the two fruit fly groups were similar in the month of February. In Monte Alegre do Sul, SP, Souza-Filho et al. (2009) recorded a population peak of A. fraterculus in March, August, and September, when the fruits ripen.

\section{Fruit fly infestation in guavas}

From the fruits collected for surveying fruit fly infestation, a total of 28 adult specimens of Anastrepha spp. (14 males and 14 females) and two males of $C$. capitata were recovered. The occurrence of A. obliqua and A. sororcula was recorded in guava fruits (Table 2). The other Anastrepha species that were captured have probably developed in hosts located near the guava orchard. In Presidente Prudente, SP, studies conducted by Montes et al. (2010; 2011a and b; 2012) documented a predominance of Anastrepha in siriguela, citrus fruits and cassava. 


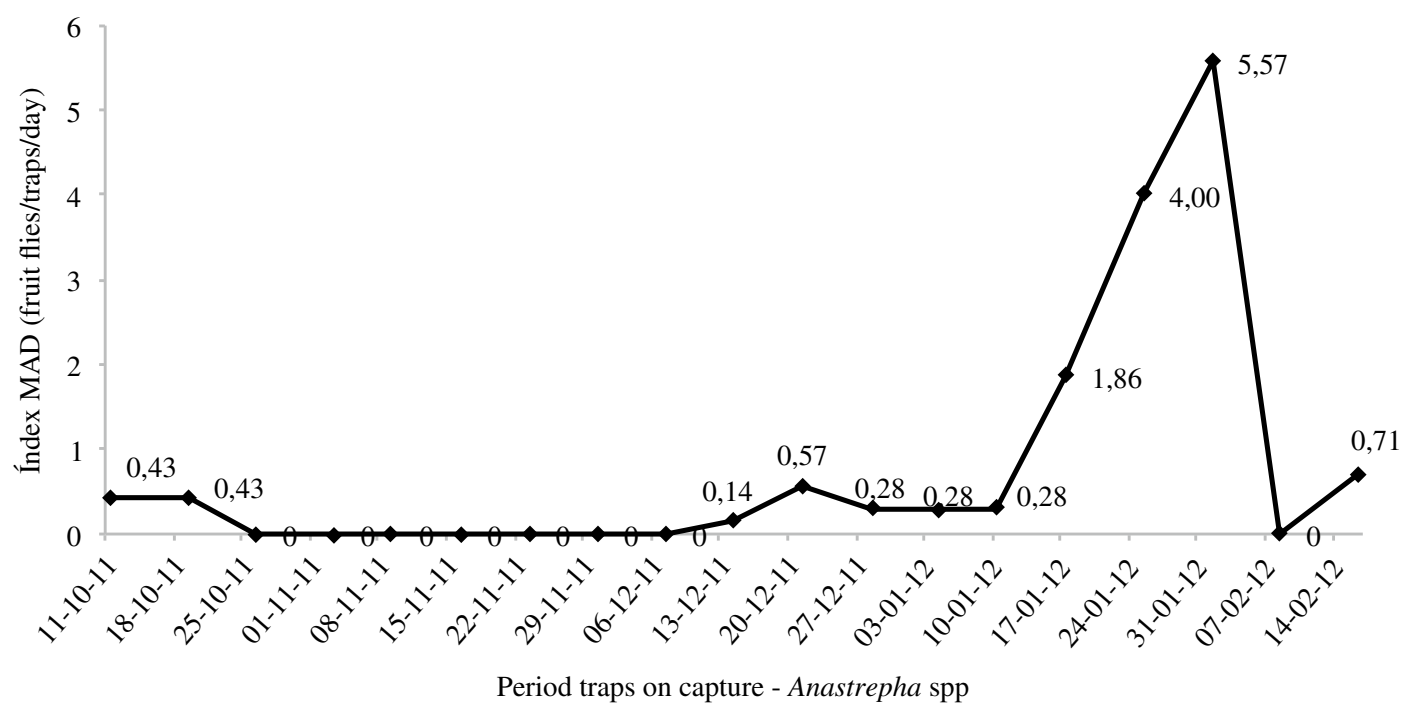

Figure 1. Population variation of Anastrepha spp. in McPhail traps, in guavas. Indiana, SP, Brazil. From Oct./2011 to Feb./2012.

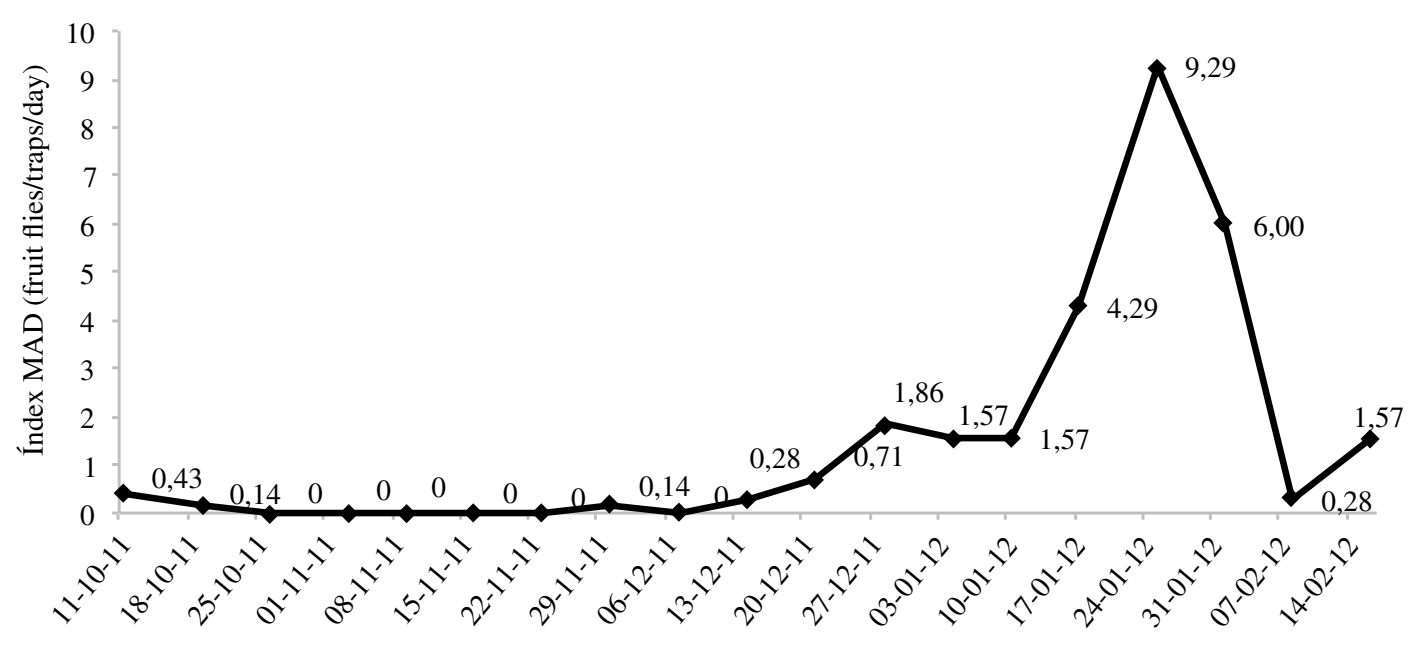

Period traps on capture Ceratitis capitata

Figure 2. Population variation of Ceratitis capitata in McPhail traps, in guavas. Indiana, SP, Brazil. From Oct/2011 to Feb/2012.

Souza-Filho et al. (2009), indentified four species of Anastrepha in guava, loquat, and peach orchards located in Monte Alegre do Sul, SP county, between 2002-2003. In guava fruits, particularly, $A$. bistrigata Bezzi, A. fraterculus (Wied.), A. obliqua Macquart, A. sororcula Zucchi and C. capitata (Wied.) were reported.

In the semi-arid Rio Grande do Norte, Araújo and Zucchi, 2003 verified that $A$. zenildae and $A$. sororcula are more adapted to that region. However, in northern Minas Gerais (Southeastern Brazil), Canal et al., $(1998,1998 \mathrm{a})$ reported the predominance of $A$. zenildae. This distinct occurrence of fruit fly species can be explained by the influence of various factors in the rate of fruit fly infestation (Nascimento et al., 1982), such as the variety planted and the proximity to other orchards (Araújo and Zucchi, 2003).

The fruit bagging and unbagging experiment demonstrated that $C$. capitata and Anastrepha adults can initiate oviposition in fruits as small as 
Table 2. Adult fruit fly rate during guava fruit growth from Paluma lineage with regard to the fortnightly bagging and unbagging period. Indiana, SP, Brazil. 2011.

\begin{tabular}{|c|c|c|c|c|c|c|c|c|c|}
\hline \multirow{2}{*}{$\begin{array}{c}\text { Treatment } \\
\text { Bagging }\end{array}$} & \multicolumn{7}{|c|}{ Half of bagging and unbagging fruits } & \multicolumn{2}{|c|}{$\%$ infested fruits } \\
\hline & 0 & 1 & 2 & 3 & 4 & 5 & 6 & Anastrepha spp. & C. capitata \\
\hline 05/10/2011 & $\mathrm{X}$ & $\mathrm{X}$ & $\mathrm{X}$ & X & $\mathrm{X}$ & $\mathrm{X}$ & $X$ & 0.0 & 0 \\
\hline $19 / 10 / 2011$ & & $X$ & $\mathrm{X}$ & $X$ & $\mathrm{X}$ & $\mathrm{X}$ & $\mathrm{X}$ & 0.0 & 0 \\
\hline 03/11/2011 & & & $\mathrm{X}$ & $\mathrm{X}$ & $\mathrm{X}$ & $\mathrm{X}$ & $\mathrm{X}$ & 0.0 & 0 \\
\hline $16 / 11 / 2011$ & & & & $X$ & $\mathrm{X}$ & $\mathrm{X}$ & $\mathrm{X}$ & 0.0 & 0 \\
\hline $30 / 11 / 2011$ & & & & & $\mathrm{X}$ & $\mathrm{X}$ & $\mathrm{X}$ & 0.0 & 6.7 \\
\hline $14 / 12 / 2011$ & & & & & & $\mathrm{X}$ & $\mathrm{X}$ & 6.7 & 0 \\
\hline $28 / 12 / 2011$ & & & & & & & $\mathrm{X}$ & 0.0 & 0 \\
\hline Unbagging & 0 & 1 & 2 & 3 & 4 & 5 & 6 & & \\
\hline $19 / 10 / 2011$ & $X$ & & & & & & & 0.0 & 0 \\
\hline $03 / 11 / 2011$ & $X$ & $X$ & & & & & & 27.3 & 9.1 \\
\hline $16 / 11 / 2011$ & $X$ & $X$ & $\mathrm{X}$ & & & & & 7.1 & 0 \\
\hline $30 / 11 / 2011$ & $X$ & $X$ & $X$ & $X$ & & & & 25.0 & 0 \\
\hline $14 / 12 / 2011$ & $X$ & $X$ & $\mathrm{X}$ & $\mathrm{X}$ & $X$ & & & 20.0 & 0 \\
\hline $28 / 12 / 2011$ & $X$ & $X$ & $\mathrm{X}$ & $X$ & $X$ & $X$ & & 25.0 & 0 \\
\hline
\end{tabular}

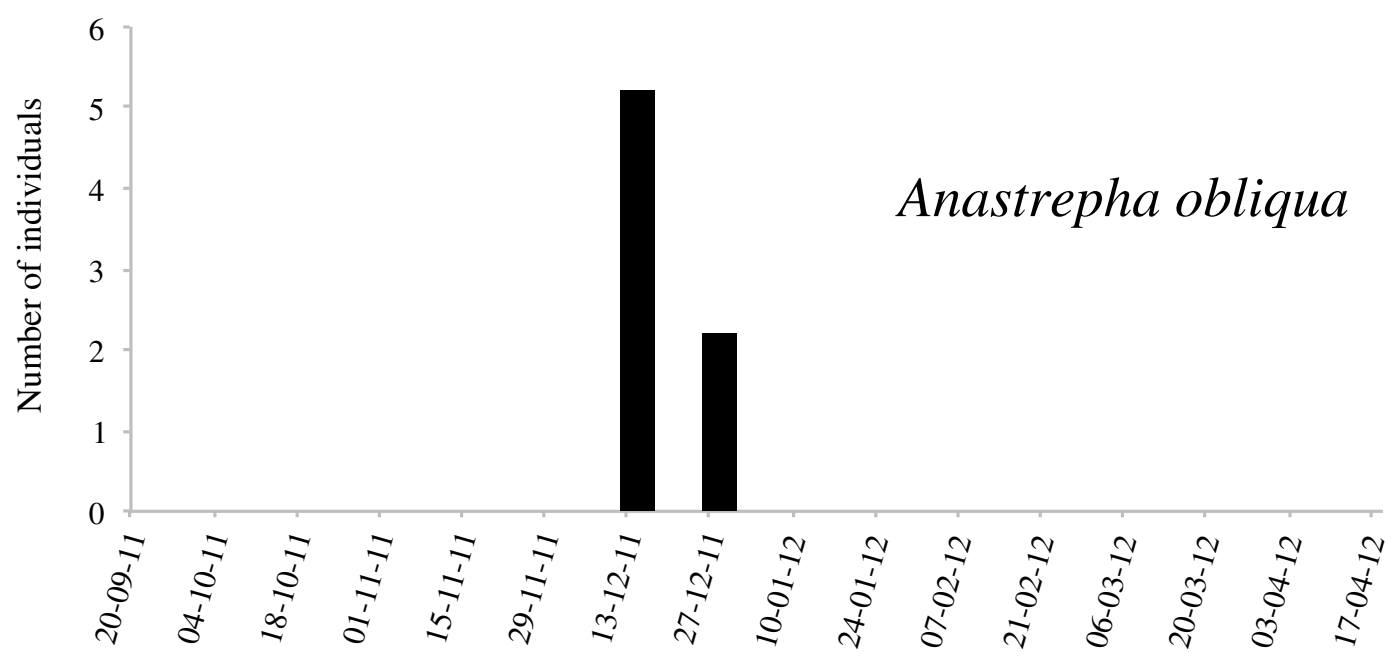

Period of occurrence

Figure 3. Anastrepha obliqua and A. sororcula infestation in guava fruits with regard to the fruit exposition period. Indiana, SP, Brazil. From Sept/2011 to Apr/2012.

2.6-cm diameter, at nine weeks of development. A similar result was obtained by Souza-Filho et al. (2009) in Monte Alegre do Sul, SP, where a fruit fly attack in guava, loquat and peaches with $2-\mathrm{cm}$ diameter fruits was identified. The highest rate of fruit infestation was $9.1 \%$ for C. capitata and $27.3 \%$ for Anastrepha (Table 2).

Diaz and Vasquez (1993) verified that the Anastrepha spp. adults could begin oviposition in young guavas around nine weeks after flowering. However, the emerged adult rate increased following fruit growth, indicating that conditions became more favorable as fruits developed.

Levels of $C$. capitata infestation in our study differed from the results of Moura and Moura (2011) in Fortaleza, Ceará. In their study, a greater increase of the $C$. capitata adult rate was observed compared to the Anastrepha spp. rate.

The lower C. capitata incidence rate relative to Anastrepha demonstrated the non-preference of the Mediterranean fly for the guava "Paluma" orchard. This fact is probably due either to the harder 


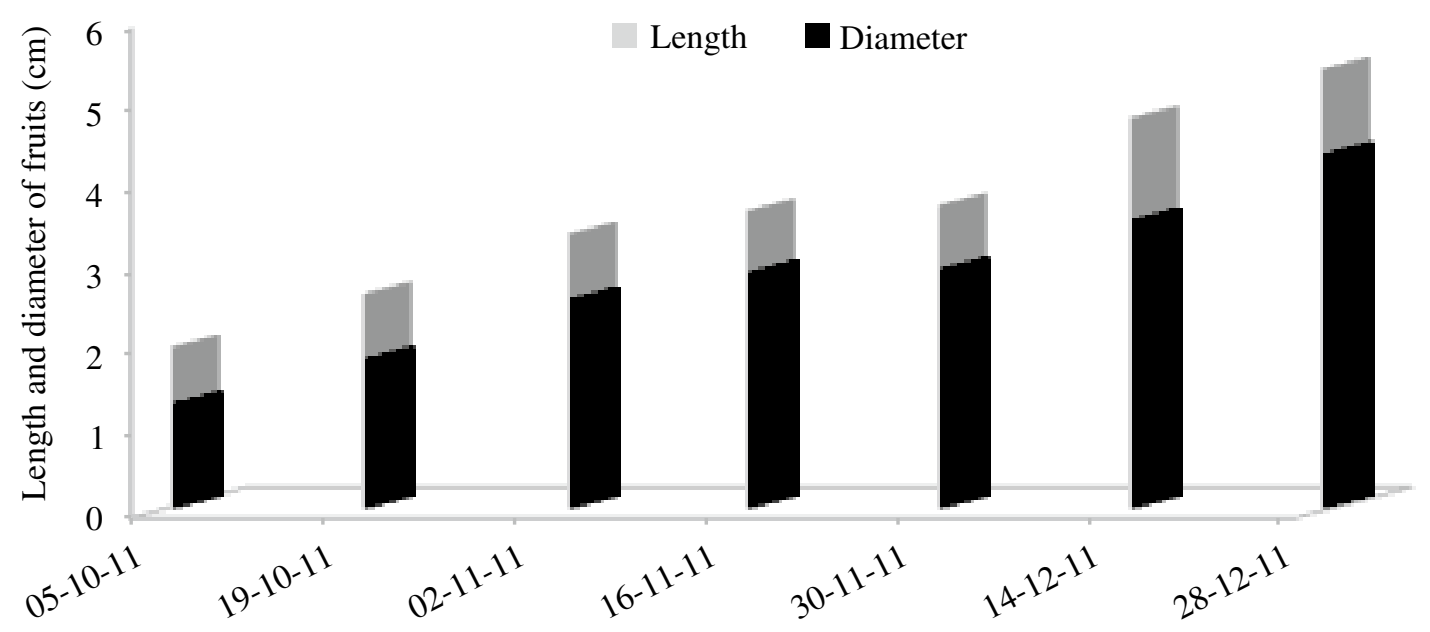

Period of evaluation

Figure 4. Fortnightly evaluation of fruit growth. Indiana, SP, Brazil. From Oct to Dec/2011.

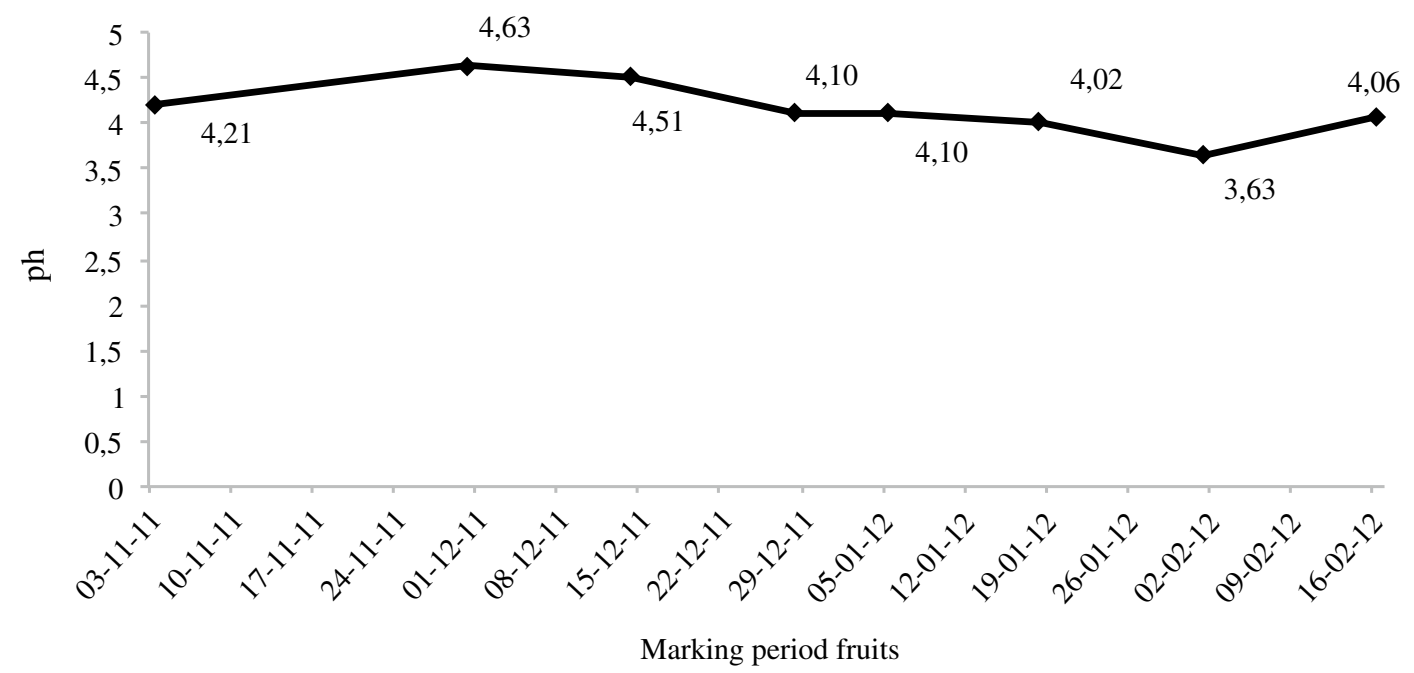

Figure 5. Chemical evaluation of guava fruit (pH). Indiana, SP, Brazil. From Nov/2011 to Feb/2012.

epidermis of the fruits or to the fruit coloration being unattractive to the females. Even though $C$. capitata was predominant in the trap collection, the flies did not attack the guava trees. They were probably infesting nearby hosts and were attracted to the solution used in the traps in our study orchard.

\section{Fruit fly infestation and the physical - chemical fruit characteristics}

The fruit $\mathrm{pH}$ was constant during growth, leading to no correlation between fruit $\mathrm{pH}$ and fruit fly population levels (Figure 5). Souza-Filho et al. (2009) only observed insignificant $\mathrm{pH}$ changes during fruit maturation, therefore, $\mathrm{pH}$ values did not have a direct correlation with the Anastrepha spp. population rate.

\section{Conclusion}

Guava fruits in their early stages of development (as small as 2.6-cm diameter) were already susceptible to attack by fruit flies. Fruit size was a reliable physical character as a susceptibility parameter for fruit fly attack. Anastrepha spp. were predominant in guava fruit infestation in Indiana county, SP, Southeastern Brazil. 


\section{Literature Cited}

Azevedo, F.R.; Guimarães, J.A.; Simplicio, A.A.F; Santos, H.R. 2010. Análise faunística e flutuação populacional de moscasdas-frutas (Diptera: Tephritidae) em pomares comerciais de goiaba na região do Cariri Cearense. Arquivos do Instituto Biológico, 77 (1): 33-41.

Araújo, E.L.; Zucchi, R.A.

2003. Moscas-das-frutas (Diptera: Tephritidae) em Goiaba (Psidium guajava L.), em Mossoró, RN. Arquivos do Instituto Biológico, São Paulo, 10 (1): 73-77.

Canal, N.A.; Alvarenga, C.D.; Zucchi, R.A.

1998. Análise faunística de espécies de moscas-das-frutas (Dip., Tephritidae) em Minas Gerais. Scientia Agricola, 55 (1): 15-25.

Canal, N.A.; Alvarenga, C.D.; Zucchi, R.A.

1998a. Níveis de Infestação de Goiaba por Anastrepha zenildae Zucchi (Diptera: Tephritidae), em Pomares Comerciais no Norte de Minas Gerais. Anais da Sociedade Entomológica, 27 (4): 657-661.

Costa, R.I.F.; Silva, C.G.; Marchiori, C.H.; Amaral, B.B.; Poletti, M.M.; Torres, L.C.

2007. Parasitismo em Anastrepha sp. (Diptera: Tephritidae) por Aganaspis pelleranoi Brethes, 1924) e Dicerataspis sp. (Hymenoptera: Figitidae: Eucoilinae). Ciência $e$ Agrotecnologia (3): 720-723.

Díaz, F.A.; Vásquez R.B.

1993. Época de oviposición de la mosca de las frutas (Anastrepha spp.) relacionada con la fenología de la guayaba nativa. Revista ICA, Bogotá 28 (4): 323-333.

Gould, W.P.; Raga, A.

2002. Pests of guava. In: Peña, J.E., Sharp, J.L., Wysoki, M. Tropical Fruit Pests and Pollinators-Biology, Economic Importance, Natural Enemies and Control. Wallingford: CAB. 295-313.

IEA-Instituto de Economia Agrícola

2011. Informações estatísticas da agricultura: produção vegetal/ produtos. São Paulo: IEA 18(1): 11-13 (Série). Disponível em http://www.iea.sp.gov.br/out/banco/menu.php.> Acesso em: 15 mar 2012.

Montes, S.M.N.M.; Raga, A.; Souza-Filho, M.F.

2010. Occurrence of fruit flies in Mango orchard in the west region of the state of São Paulo, Brazil. In: International Symposium on fruit flies of Economic Importance, 8th., 2010. Anais...Valência, ES.

Montes, S.M.N.M.; Raga, A.; Souza-Filho, M.F.

2011a. Levantamento de espécies de Anastrepha (Diptera: Tephritidae) em áreas de Cucurbitaceae sob sistema de mitigação de risco. Arquivos do Instituto Biológico, 78 (2): 317-320.

Montes, S.M.N.M.; Raga, A.; Boliani, A.C.; Santos, P.C.

2011b. Dinâmica populacional e incidência de moscas-das-frutas e parasitóides em cultivares de pessegueiros (Prunus persica L. Batsch) no município de Presidente Prudente. Revista Brasileira de Fruticultura, Jaboticabal, 33 (2): 402-411.
Montes, S.M.N.M.; Raga, A.; Souza-Filho, M.F.; Strikis, P.C.;

Santos, P.C.

2012. Moscas-das-frutas em cultivares de cafeeiros de Presidente Prudente, SP. Coffee Science, Lavras 7 (2): 99-109.

Moura, A.P. de; Moura, D.C.M. de

2011. Levantamento e flutuação populacional de parasitóides de moscas-das-frutas (Diptera: Tephritidae) de ocorrência em goiabeira (Psidium guajava L.) em Fortaleza, Ceará. Arquivos do Instituto Biológico, 78 (2): 225-231.

Nascimento, A.S.; Zucchi, R.A.; Morgante, J.S.; Malavasi, A. 1982. Dinâmica populacional das moscas-das-frutas do gênero Anastrepha (Dip., Tephritidae) no Recôncavo baiano.llflutuação populacional. Pesquisa Agropecuária Brasileira, 17: 969-980.

Pereira, F.M.

1995. Cultura da goiabeira. Jaboticabal: FUNEP, 47 pp.

Pereira, F.M.; Martínez Junior, M.

1986. Goiaba para industrialização. Jaboticabal: Legis Summa, $142 \mathrm{pp}$.

Raga, A.; Machado, R.A.; Souza-Filho, M.F.; Sato, M.E.;

Siloto, R.C.

2005. Tephritoidea (Diptera) species infesting Myrtaceae fruits in the State of São Paulo, Brazil. Entomotropica 20 (1): 11-14.

Salles, L.A.B.

1994. Períodos de ataque e controle da mosca-das-frutas em pessegueiro. Horti Sul, Pelotas, 3 (1): 47-51.

Scoz, P.L.; Botton, M.; Garcia, M.S.; Pastori, P.L.

2006. Avaliação de atrativos alimentares e armadilhas para o monitoramento de Anastrepha fraterculus (Wiedemann, 1830) (Diptera: Tephritidae) na cultura do pessegueiro [(Prunus persica (L.) Batsh]. Idesia, 24 (2): 7-13.

Souza-Filho, M.F.; Raga, A.; Azevedo-Filho, J.A.; Strikis, P.C.; Guimarães, J.A.; Zucchi, R.A.

2009. Diversity and sasonality of fruit flies (Diptera: Tephritidae and Lonchaeidae) and their parasitoids (Hymeoptera: Braconidae and Figitidae) in orchards of guava, loquat and peach. Brazilian Journal Biology, 69 (1): 31-40.

Steyskal, G.C.

1977. Pictorial key to species of the genus Anastrepha (Diptera: Tephritidae). The Entomological Society of Washington. $35 \mathrm{pp}$.

Zucchi, R.A.

2000a. Taxonomia. p. 13-24. In: Malavasi, A., Zucchi, R. A.(eds.). Moscas-das-frutas de importância econômica no Brasil: conhecimento básico e aplicado. Ribeirão Preto,: Holos. 327 pp.

Zucchi, R.A.

2000b. Espécies de Anastrepha, Sinonímias, Plantas hospedeiras e Parasitóides. p. 41-48. In: Malavasi, A., Zucchi, R.A. (eds.). Moscas-das-frutas de importância econômica no Brasil: conhecimento básico e aplicado. Ribeirão Preto,: Holos. 327 pp. 
